\title{
Methicillin Resistant Staphylococcus aureus: Knowledge and Factors Related to the Nursing Team's Adherence to Preventive Measures
}

\author{
Adriana Maria da Silva ${ }^{1}$ \\ Milton Jorge de Carvalho ${ }^{2}$ \\ Silvia Rita Marin da Silva Canini ${ }^{3}$ \\ Elaine Drehmer de Almeida Cruz ${ }^{4}$ \\ Carmen Lucia Antunes Pimenta Simões ${ }^{5}$ \\ Elucir Gir ${ }^{6}$
}

This study evaluated the knowledge of a nursing team from a public hospital in the state of São Paulo, Brazil concerning preventive measures recommended in the care delivered to patients colonized with Methicillin Resistant Staphylococcus Aureus (MRSA) and, through the Health Beliefs Model, identified the factors influencing adherence or non-adherence to preventive measures. A total of 318 professionals from different units participated in the study. According to the analysis, the nursing team's knowledge and perception of MRSA susceptibility was limited, which indicates the need for actions to improve the understanding of preventive measures employed in the care delivered to patients colonized or infected by this microorganism.

Descriptors: Nursing, Team; Methicillin Resistance; Health Knowledge, Attitudes, Practice.

\footnotetext{
${ }^{1}$ RN, Doctoral Student, Escola de Enfermagem de Ribeirão Preto, Universidade de São Paulo, WHO Collaborating Centre for Nursing Research Development, SP, Brazil. E-mail: adriusprp@yahoo.com.br.

2 Physician, Faculty, Faculdade de Medicina do ABC, SP, Brazil, E-mail: mjmulher@uol.com.br.

${ }^{3}$ RN, Ph.D. in Nursing, Faculty, Escola de Enfermagem de Ribeirão Preto, Universidade de São Paulo, WHO Collaborating Centre for Nursing Research Development, SP, Brazil. E-mail: canini@eerp.usp.br.

${ }^{4}$ RN, Faculty, Departamento de Enfermagem, Universidade Federal do Paraná, PR, Brazil. E-mail: elainedrehmer@yahoo.com.br.

${ }^{5}$ RN, Hospital Estadual Mário Covas, Santo André, SP, Brazil. E-mail: csimoes@hesa-fuabc.org.br.

${ }^{6}$ RN, Ph.D. in Nursing, Full Professor, Escola de Enfermagem de Ribeirão Preto, Universidade de São Paulo, WHO Collaborating Centre for Nursing Research Development, SP, Brazil. E-mail: egir@eerp.usp.br.
}

Corresponding Author:

Adriana Maria da Silva

Hospital do Coração, Associação do Sanatório Sírio. Serviço de Controle de

Infecção e Epidemiologia Hospitalar

Rua Abílio Soares, 250, $8^{\circ}$ andar

Bairro: Paraíso

CEP: 04005-000 São Paulo, SP, Brasil

E-mail: adriusprp@yahoo.com.br 


\title{
Staphylococcus aureus resistente à meticilina: conhecimento e fatores associados à adesão da equipe de enfermagem às medidas preventivas
}

Este estudo teve como objetivos avaliar o conhecimento da equipe de enfermagem de um hospital público do Estado de São Paulo sobre as medidas preventivas, recomendadas na assistência a indivíduos colonizados com Staphylococcus aureus resistente à meticilina (MRSA) e identificar os fatores que influenciam na adesão ou não adesão às medidas preventivas, segundo o modelo de crenças em saúde. Trata-se de estudo descritivo, com abordagem quali-quantitativa, no qual participaram 318 profissionais de diferentes setores da instituição. De acordo com a análise realizada, o conhecimento da equipe de enfermagem, assim como a percepção de suscetibilidade ao MRSA, foi limitado, demandando ações para melhor compreensão das medidas preventivas empregadas na assistência a pacientes colonizados ou infectados por esse microrganismo.

Descritores: Equipe de Enfermagem; Resistência a Meticilina; Conhecimentos, Atitudes e Prática em Saúde.

\section{Staphylococcus aureus resistente a la meticilina: conocimiento y factores asociados a la adhesión del equipo de enfermería a las medidas preventivas}

\begin{abstract}
Este estudio tuvo como objetivos evaluar el conocimiento del equipo de enfermería, en un hospital público del Estado de Sao Paulo, sobre las medidas preventivas recomendadas en la asistencia a individuos colonizados con Staphylococcus aureus resistente a la meticilina (MRSA) e identificar los factores que influyen en la adhesión o no adhesión a las medidas preventivas, según el modelo de creencias en salud. Se trata de un estudio descriptivo, con abordaje cualitativo-cuantitativo, en el cual participaron 318 profesionales de diferentes sectores de la institución. De acuerdo con el análisis realizado, el conocimiento del equipo de enfermería, así como la percepción de susceptibilidad al MRSA, fue limitado, demandando acciones para mejorar la comprensión de las medidas preventivas empleadas en la asistencia a pacientes colonizados o infectados por ese microorganismo.
\end{abstract}

Descriptores: Grupo de Enfermería; Resistencia a la Meticilina; Conocimientos, Actitudes y Práctica en Salud.

\section{Introduction}

Staphylococcus aureus is a gram-positive bacterium whose main reservoir is the human being. It is usually isolated in the nostrils, skin and perineum of healthy individuals and is considered an opportunistic human pathogen, frequently associated with infections acquired in the community and in hospital settings ${ }^{(1)}$. The most common infections involve the skin (impetigo, cellulites) and wounds can be spread to different tissues ${ }^{(2)}$.

Methicillin-Resistant Staphylococcus Aureus (MRSA) was detected in 1961, one year after methicillin was launched as the drug of choice to treat infections caused by strains of Staphylococcus aureus, a producer of penicillinase. From the 1980s on, MRSA has been an endemic problem worldwide, including Brazil(1).

The use of contact precautions aims to break the links in the chain of transmission of microorganisms, such as the transmission of pathogens from the hands of health professionals (HP) to the environment, equipment and patients ${ }^{(3)}$. This type of precaution requires HP to wash their hands, use gloves and aprons before having contact with a colonized or infected patient ${ }^{(4)}$. However, research has shown that HP adherence to these measures 
is still unsatisfactory ${ }^{(5)}$, which contributes to the risk of infection in health care settings.

Few Brazilian studies address this issue ${ }^{(6-8)}$ despite the relevance of MRSA as a cause of hospital-acquired infections and the role of HP as potential disseminators of this microorganism.

Understanding the reasons that lead nursing professionals to adhere or not to preventive measures recommended in the care delivered to MRSA carriers means to understand the influence of environmental and psychosocial factors on the behavior of these professionals $^{(7)}$ and thereby contribute to the implementation of preventive measures.

Based on these factors, this study evaluated the knowledge of the nursing team of a large public hospital concerning the recommended preventive measures to be adopted in the care delivered to MRSA carriers and identified the factors that influence adherence and non-adherence to these measures according to the content analysis technique ${ }^{(9)}$ and the Health Belief Model $(\mathrm{HBM})^{(10)}$.

Westress that thisstudyoffersimportantcontributions to this periodical since the last article addressing nursing-related colonization by Staphylococcus aureus, with students from an nursing auxiliary program, dates from $2000^{(2)}$. Readdressing this issue is justified by the importance attributed to it in the last decade, especially because nursing professionals are acknowledged vehicles disseminating this microorganism, and also due to the impact of this microorganism on the epidemiological scenario of infections associated with health care. This is a reemerging issue and related knowledge expressively supports the nursing praxis and health institutions.

\section{Method}

This descriptive study with quantitative and qualitative analysis was approved by the Research Ethics Committee at the Faculty of Medicine of $A B C$, Brazil (Protocol CEP/ FMABC, n.242/2006).

The study's sample was composed of nurses, nursing technicians and auxiliaries from the centers of hospitalization, surgery, intensive therapy, nursing, pediatrics, surgery and emergency units of a state large hospital in the state of São Paulo and who were professionally active at the time of data collection in 2007 and 2008.

The data collection instrument, containing open, semi-open and closed questions was developed by the researchers to find elements that would clarify the four dimensions of HBM. It was submitted to experts who judged its face and content validity.

Data collection was initiated after HP were invited to participate in the study and those who agreed signed free and inform consent forms and were ensured confidentiality of the gathered information. Data were organized and processed in the SPSS version 15.0. The answers to closed questions were evaluated through descriptive statistics and open questions were analyzed through content analysis ${ }^{(9)}$ and $\mathrm{HBM}^{(10)}$.

\section{Results}

Results are presented in three stages: characterization of nursing professionals, causes of multi-resistance and HBM dimensions.

\section{Characterization of nursing professionals}

A total of 318 nursing professionals participated in the study. $76.7 \%$ (244/318) were women; $55.7 \%$ (177/318) were nursing auxiliaries; $31.1 \%$ (99/318) nursing technicians and $13.2 \%(42 / 318)$ nurses.

\section{Causes of multi-resistance}

The professionals were asked about the reasons Staphylococcus aureus become resistant to antimicrobials: $43.7 \%(139 / 318)$ of the interviewees reported not knowing the reason, 22\% (70/318) reported it is a consequence of inappropriate use of antimicrobials, $13.8 \%(44 / 318)$ attributed it to inappropriate treatment, $11.6 \%(37 / 318)$ attributed it to natural selection and $8.8 \%(28 / 318)$ to inappropriate manipulation of antibiotics.

\section{Belief Model Dimensions}

In relation to the HBM's first dimension, perception of susceptibility, when HP were asked whether MRSA could pose risks to themselves and clients, $78.3 \%$ (249/318) answered yes and 21.7\% (69/318) answered no. Among the risks attributed to the team, $39.3 \%$ (98/249) acknowledged the risk of cross transmission and $32.9 \%$ (82/249) severity of infection.

About the concern of acquiring MRSA while taking care of a colonized/infected patient, 92.8\% (295/318) expressed being concerned with the possibility: $31.8 \%$ (94/295) reported fear of becoming sick, 20\% (59/295) limited alternatives of treatment and $12.8 \%$ (38/295) stressed fear of transmitting the disease to family members, while 23 (7.2\%) professionals denied such a concern. 
When participants were asked about precautions employed while delivering care to patients with MRSA, $70.1 \%(223 / 318)$ reported the use of standard precautions and $11 \%(35 / 318)$ contact precautions; 60 professionals (18.9\%) did not answer this question.

In relation to the frequency of hand washing when delivering care to patients with MRSA, 89.6\% (285/318) claimed they washed hands with the same frequency regardless of the patients' condition, and $10.4 \%$ (33/318) reported washing hands with greater frequency.

In relation to the HBM's second dimension, perception of severity, $62.7 \%(198 / 318)$ of workers report MRSA cause severe infections, with high rate of mortality and is difficult to treat and $37.7 \%$ (120/318) did not associate this bacterium with more severe infections.

The vast majority, 94.6\% (301/318), acknowledged that the use of preventive measures can benefit HP and $98.1 \%$ (312/318) highlighted the benefits for patients, while the main benefit was prevention of infections, which fits the third dimension, perceived benefits.

The HBM's fourth dimension, perceived barriers, investigated whether other professionals' non-adherence to preventive measures influenced the team's behavior and was therefore considered a barrier. Answers revealed that $59.8 \%(190 / 318)$ believe it does not influence the team's behavior, however, $29.2 \%$ (93/318) of the participants reported they believed that non-adherence to preventive measures negatively influences the team's behavior.

The factors that facilitate professionals' adherence to preventive measures recommended during care delivered to patients with MRSA are, in the view of the participants: availability of personal protective equipment (PPE) (39.9\%), appropriate number of professionals $(22.9 \%)$, teamwork (16.9\%), training and education $(9.7 \%)$, early identification of microorganisms $(5.9 \%)$, and information regarding the need to isolate the patient $(3.7 \%)$. The factors hindering adherence are: absence of PPE (29.8\%), lack of training and education programs $(19.8 \%)$, lack of teamwork (17.9\%), late diagnosis $(9.7 \%)$, insufficient number of professionals $(8.8 \%)$, lack of information regarding the need to isolate the patient $(6.9 \%)$, and emergency situations (5.9\%). It is worth mentioning that participants indicated more than one item.

\section{Discussion}

Results show that $43.7 \%$ of the professionals from the nursing team did not know the basis of the Staphylococcus aureus' resistance to methicillin.
Similar studies carried out with HP in Minas Gerais and Paraná, Brazil presented divergent results. Only $1.8 \%$ of the 42 nursing professionals investigated in the study carried out in Minas Gerais did not know the basis of the multi-resistance ${ }^{(7)}$. The study carried out in Paraná, and which included $486 \mathrm{HP}$, showed that $6.6 \%$ of the medical team, $24.9 \%$ of the nursing team, $30.4 \%$ of the physiotherapy and occupational therapy and $87.3 \%$ of the cleaning team did not know the basis of multiresistance ${ }^{(6)}$.

Nursing professionals' knowledge is essential for the adoption of prevention measures and control of MRSA, though, knowledge per se does not determine the behavior of professionals in daily practice ${ }^{(6)}$. Hence, some scholars emphasize the need to identify the health beliefs of these workers, since these beliefs can be an efficient tool to identify and understand risk behaviors and to develop strategies of prevention and control of MRSA dissemination(6).

The perception of susceptibility is described as the "subjective perception of personal risk to acquire a disease"(10). In relation to this category, $92.7 \%$ of the interviewees reported they become concerned when delivering care to patients with MRSA and $78.3 \%$ acknowledge the risks to which they are exposed. The HP's perceived susceptibility in relation to the risk of acquiring MRSA might contribute to the development of preventive behaviors, though $7.2 \%$ are not concerned and $21.6 \%$ believe risks do not exist. Recent investigations report similar results ${ }^{(6-7,11)}$.

We highlight that $21.6 \%$ of the participants do not believe in the risks associated with MRSA, which might lead a colonized professional to trigger outbreaks in the hospital setting and in the community. Researchers evaluating the role of HP in MRSA outbreaks in 1992 found that $53(3.4 \%)$ out of the 1,547 evaluated professionals were colonized by MRSA(12), which reinforces the need to consider HP as important reservoirs of this agent in situations of hospital outbreaks.

One study addressing outbreaks of MRSA in 2007 found that $25(80.6 \%)$ out of the 31 patients isolated with MRSA were associated with the strain of a colonized $\mathrm{HP}^{(13)}$. Therefore, there is evidence that HP present a risk of colonization and dissemination of MRSA. From this perspective, the fear to transmit the disease to family members, reported by $12.8 \%$ (38/295) of professionals, is justified since the colonization of HP by MRSA represents two different risks: source of infection to hospitalized patients and to HP's family members or both $^{(14)}$. 
One study carried out with family members of HP colonized by MRSA concluded that of the 21 evaluated family members, six (28.5\%) presented MRSA in the anterior nostril. Genetic analysis by pulsed field gel electrophoresis (PAGE) showed that the strain isolated from the HP was the same isolated in their relatives ${ }^{(15)}$.

The fact that only 11 (35/318) of the professionals reported the use of contact precautions when delivering care to patients with MRSA is a concern since it is a recommendation with solid evidence from the literature ${ }^{(3,16-17)}$. However, this result reveals that despite the susceptibility perceived by the majority of HP, their behavior is inconsistent with their beliefs.

From this same perspective, only $10.3 \%$ (33/318) of the nursing team reported increased frequency of hand washing when delivering care to patients with MRSA. Similarly, in another study, the practice of hand washing was not related to the fact that patients were carrying the microorganism or not ${ }^{(6)}$.

Perception of severity is understood as "the degree of emotional disturbance provoked when one thinks on the disease and its potential consequences: pain, death, material expenditure, interruption of activities, disarrangement of family relationships, etc..."(10). In this dimension, $92.7 \%$ (198/318) of the participants reported being concern about acquiring MRSA, which were expressed as severe infections, high rates of mortality and difficult treatment, while 37.7\% (120/318) did not associate MRSA with more severe infections.

Colonized patients and professionals are at the risk of developing infections caused by MRSA; from 30 to $60 \%$ of colonized patients develop infections(18). The use of more expensive antimicrobials, higher number of laboratory services and increased time of hospitalization are factors that increase the costs of treatments of infections caused by $\mathrm{MRSA}^{(14)}$, whereas the rates of mortality related to this kind of infection vary from $49 \%$ to $55 \%{ }^{(1)}$.

The perceived benefits are understood as "the belief in the effectiveness of an action and the perception of its positive consequences"(10). In this category, $94.6 \%$ (301/318) of the participants reported that the use of preventive measures could benefit HP and $98.1 \%$ (312/318) reported that patients would be benefited, while prevention of infections was indicated as the main positive action. This result is similar to that found in the literature ${ }^{(7)}$. The belief that a preventive behavior results in benefits is an important factor in the studied context because it favors and encourages prevention.
Perceived barriers are defined as "the negative aspects of an action, which are evaluated in a cost/ benefit analysis, considering potential expenditure of time, money, effort, trouble, etc..."(10). A barrier perceived by participants in this study was non-adherence of other professionals to the preventive measures, described by $28.3 \%$ (93/328) of participants. According to them, this behavior negatively influences the team, since it encourages error and leads to concern.

Yet, investigating the perceived barriers, we found that the conditions associated with the institutions (availability of PPE, adequate number of professionals), teamwork and knowledge (training, education) were described as the main factors facilitating or hindering professionals' adherence to preventive measures. These same conditions were described in the literature in two Brazilian studies ${ }^{(6-7)}$.

One study ${ }^{(19)}$ that evaluated the knowledge and behavior of professionals from an intensive care unit in relation to adoption of contact precautions, showed that there was no association between knowledge and behavior.

A traditional training program can transmit information but not necessarily influence change of behavior(20). Thus, health institutions should invest in innovating strategies, capable of changing the health professionals' perception of vulnerability and consequently encourage them to adopt preventive measures.

\section{Final Considerations}

According to the analysis, the knowledge of health professionals concerning MRSA is limited and needs to be broadened so that HP have a better theoretical support and understand the relevance of preventive measures in care delivered to patients with MRSA. The use of HBM permitted identifying factors that facilitate and hinder adherence to these measures, though perceived susceptibility and severity do not result in the adoption of preventive measures, such as contact precaution and hand washing, which indicate the need for additional studies addressing the issue from this perspective and other factors intervenient in the behavior of HP.

Controlling and preventing the dissemination of MRSA is essential for nursing practice and safety of patients. The HP's awareness and understanding that they are potential disseminators of this microorganism is fundamental to the daily adoption of measures necessary to break the chain of transmission of these agents in the health care setting. 


\section{References}

1. Rossi F, Andreazzi D. Resistência bacteriana. Interpretando o antibiograma. São Paulo: Atheneu; 2005.

2. Santos BMO. Monitoramento da colonização pelo Staphylococcus aureus em alunos de um curso de auxiliar de enfermagem durante a formação profissional. Rev. Latino-Am. Enfermagem. 2000; 8(1):67-73.

3. Siegel JD, Rhineheart E, Jackson M, Chiarello L. Management of Multidrug-Resistant Organisms in Healthcare Settings 2006. Healthcare Infection Control Practices Advisory Committee (HICPAC) 2006 [Cited: 2008 October 20]. Available from: http:// www.cdc.gov/ncidod/dhqp/pdf/ar/mdroGuideline2006.pdf.

4. Siegel JD, Rhineheart E, Jackson M, Chiarello L. Health Care Infection Control Practices Advisory Committee AJIC. Guideline for Isolation Precautions: preventing transmission of infectious agents in health care settings. Am J Infect Control. 2007;35(10):S65-S164.

5. Gammon J, Morgan-Samuel H, Gould D. A review of the evidence for suboptimal compliance of healthcare practitioners to standard/universal infection control precautions. J Clin Nurs. 2008;17(2):157-67.

6. Cruz EDA. Staphylococcus aureus e Staphylococcus aureus resistentes à meticilina em trabalhadores de um hospital universitário: colonização e crenças em saúde. Tese [Doutorado em Enfermagem]- Ribeirão Preto (SP): Escola de Enfermagem de Ribeirão Preto USP; 2008.

7. Moura JP, Gir E. Nursing staff knowledge of multi-resistant bacterial infections. Acta Paul Enferm. 2007; 20(3):351-6.

8. Carvalho MJ, Pimenta FC, Hayashida M, Gir E, Silva AM, Barbosa CP, Canini SRMS, Santiago S. Prevalence of methicillinresistant and methicillin-susceptible $S$. aureus in the saliva of health professionals. Clinics. 2009; 64(4):295-302.

9. Bardin L. Análise de Conteúdo. Lisboa: Edições 70; 1997. 10. Rosenstock IM. Historical origins of the health belief model. Health Educ Monographs. 1974; 2(4):328-35.

11. Wolf R, Lewis D, Cochran R, Richards C. Nursing staff perceptions of methicillin-resistant Staphylococcus aureus and infection control in a long-term care facility. ] Am Med Dir Assoc. 2008; 9(5):342-6.
12. Lopez-Alcalde J, Conterno LO, Mateos-Mazón M, GuevaraEslava M, Job-Neto $F$, et al. Gloves, gowns and masks for reducing the transmission of meticillin-resistent Staphylococcus aureus (MRSA) in the hospital setting (Protocol for a Cochrane Review). The Cochrane Library Oxford: Update Software 2008 [Cited: 2008 April 23];(2). Disponível em: http://cochrane. bvsalud.org/cochrane/main.php?lang=pt\&lib=COC

13. Coombs GW, Van Gessel H, Pearson JC, Godsell MR, O'Brien FG, Christiansen KJ. Controlling a multicenter outbreak involving the New York/Japan methicillin-resistant Staphylococcus aureus clone. Infect Control Hosp Epidemiol. 2007; 28(7):845-52.

14. Abudu L, Blair I, Fraise A, Cheng KK. Methicillin-resistant Staphylococcus aureus (MRSA): a community-based prevalence survey. Epidemiol Infect. 2001; 126(3):351-6.

15. Eveillard M, Martin Y, Hidri N, Boussougant Y, Joly-Guillou ML. Carriage of methicillin-resistant Staphylococcus aureus among hospital employees: prevalence, duration, and transmission to households. Infect Control Hosp Epidemiol. 2004; 25(2):114-20. 16. Mears A, White A, Cookson B, Devine M, Sedgwick J, Phillips $E$, et al. Healthcare-associated infection in acute hospitals: which interventions are effective? J Hosp Infect. 2009; 71(4):307-13. 17. Lepelletier D, Corvec S, Caillon J, Reynaud A, Roze JC, GrasLeguen C. Eradication of methicillin-resistant Staphylococcus aureus in a neonatal intensive care unit: Which measures for which success? Am J Infect Control. 2009; 37(3):195-200.

18. Cosgrove SE, QI Y, Kaye KS, Harbarth S, Karchmer AW, Carmeli Y. The impact of methicillin resistance in Staphylococcus aureus bacteremia on patient outcomes: mortality, length of stay, and hospital charges. Infect Control Hosp Epidemiol. 2005; 26(2):166-74.

19. Oliveira AC, Cardoso CS, Mascarenhas D. Conhecimento e comportamento dos profissionais de enfermagem de um centro de terapia intensiva em relação à adoção das precauções de contato. Rev. Latino-Am. Enfermagem. 2009; 17(5):625-31. 20. Canini SRMS, Moraes AS, Gir E, Freitas ICM. Fatores associados a acidentes percutâneos na equipe de enfermagem de um hospital universitário de nível terciário. Rev. Latino-Am. Enfermagem. 2008, 16(5):818-23.

Received: May. $13^{\text {th }} 2009$

Accepted: Dec. 21 2009 